\title{
Ultrastructural and biochemical changes at the preinfection stage of mycorrhizal formation by two isolates of Pisolithus tinctorius
}

\author{
F. Lapeyrie', J. Lei², N. Malajczuk³ and J. Dexheimer² \\ 1 INRA, Centre de Recherches Forestières de Nancy, 54280 Seichamips, France, \\ 2 Université Nancy I, Biologie des Ligneux, 54500 Vandœuvre, France, and \\ 3 CSIRO, Division of Forestry and Forest Products, Private Bag PO, Wembley WA 6014, Australia
}

Introduction

In a previous paper, Malajczuk et al. (1989) demonstrated major infection differences existing between isolates of Pisolithus tinctorius on roots of Eucalyptus urophylla. A strain originally isolated from under Eucalyptus in Australia (445) appeared to be much more aggressive toward this host plant than one isolated from under Pinus in North America (270), despite the fact that ultimately the mycorrhizal infection occurs in both cases. To date, there have been no hypotheses to explain ectomycorrhizal specificity and aggressiveness, although the action of anti-fungal compounds originating from the plant has been suggested (Duchesne et al., 1987). Information from plant pathology literature has implicated chemical messengers as being responsible for specificity and aggressivity (Halverson and Stacey, 1986). Recently, there have been a number of publications examining early stages of mycorrhizal infection especially using Eucalyptus as the plant model (Malajczuk et al., 1984; Massicotte et al., 1987; Horan el al., 1988). In all these studies, however, the very early stages of plant-fungus contact, i.e., occurring before the ectomycorrhizal infection sensus stricto, have been overlooked. It would seems reasonable to assume that specificity and aggressivity of the infection process is determined and could therefore be characterized, during the very early events of plant-fungus interaction, as soon as recognition between both symbionts had occurred.

\section{Materials and Methods}

Plant materials and mycorrhizal synthesis were according to Malajczuk et al. (1989). Fine lateral roots were sampled after 2 and $4 \mathrm{~d}$ of incubation and processed according to Lei (1988) for electron microscopy observations, ultra- 

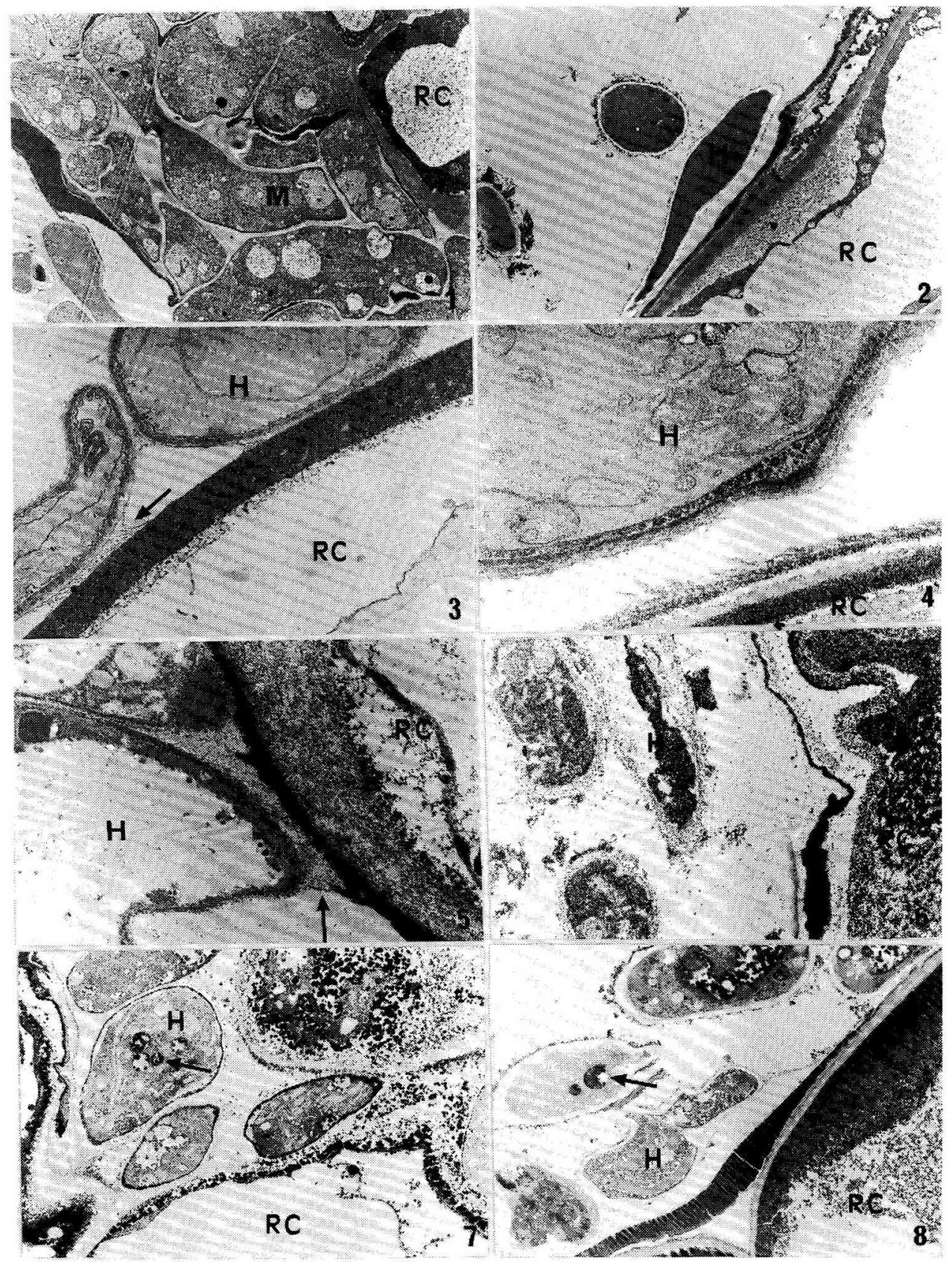

Figs. 1-8. RC: root cortical cell; H: hyphae; M: fungal mantle. 
structural localization of polysaccharides and proteins, and measurement of acid phosphatase activities.

\section{Results}

Four days after inoculation with strain 445, the fungal sheath was well established and compact (Fig. 1, $\times 3200$ ). The typical one-layer Hartig net was well developed. With strain 270 , most of the hyphae were still some distance from the root surface. Where the hyphae are in contact with the root, a thickening of the host plant cell wall can be observed, resulting from deposition of dense granular or fibrillar materials on the internal wall face (Fig. $2, \times 3100$ ).

Two days after inoculation with strain 445 , hyphae were in contact with cortical cells and polysaccharidic fibrillar material, reacting in the PATAg test, can be observed between both organisms (Fig. 3, $x$ 25000 ). These fibrils reacted positively in the Swift test indicating the presence of cystine-rich proteins (Fig. 5, x 13000 ). With strain 270, 4 days after inoculation, root cell walls as well as fungal cell walls were highly reactive in the PATAg test, but no fibrillar materials could be detected between root and fungal cells (Fig. 4, $x$ 20 000). The Swift test was equally nonreactive in this zone (Fig. $6, \times 10000$ ).

Four days after inoculation with strain 445 , acid phosphatase activity was in evidence at the surface of the fungal plasmalemma as well as in the vacuoles. The plasmalemmal activity was detected when the hyphae were close to the roots, while it was nearly absent in hyphae distant from the root (Fig. 7, x 4000). In the host-plant cells, acid phosphatase activities were localized along the plasmalemma. With strain 270 , acid phosphatase activity was detected only in fungal vacuoles (Fig. $8, \times 4600$ ).

\section{Discussion and Conclusion}

The ultrastructural comparison of the early events of infection between $E$. urophylla and both strains of $P$. tinctorius shows important differences at the interface. Indeed, it seems that the plant reacts to the presence of $P$. tinctorius isolated from under pine, as if it were in contact with a pathogenic strain. Field results shows that this strain has a poor ability to resist competition with indigenous fungi associated with Eucalyptus in plantations in the Congo (Garbaye et al., 1988). Understanding recognition is therefore quite important for the controlled utilization of mycorrhizal symbionts in plantation management.

Presently, we do not have any knowledge regarding the nature of the signal from each organism, which initiates this succession of early events of mycorrhizal infection and which determines this selective aggressiveness. It can be suggested that cell surface glycoproteins are playing an important role during recognition but no evidence has yet been given.

\section{References}

Duchesne L.C., Peterson R.L. \& Ellis B.E. (1987) The accumulation of plant-produced antimicrobial cornpounds in response to ectomycorrhizal fungi: a review. Phytoprotection 68, 17-27

Garbaye J., Delwaulle J.C. \& Diangana D. (1988) Growth response of eucalypts to mycorrhizal inoculation in the Congo. For. Ecol. Manag. 24, 151-157 
Halverson L.J. \& Stacey G. (1986) Signal exchange in plant-microbe interactions. Microbiol. Rev. 50, 193-225

Horan D.P., Chilvers G.A. \& Lapeyrie F.F. (1987) Time sequence of the infection process in eucalypt ectomycorrhizas. New Phytol. 109, $451-458$

Lei J. (1988) Etude expérimentale des systèmes symbiotiques mycorhiziens de quelques essences ligneuses, application pratique à la mycorhization de vitroplants. Ph.D. Thesis, Université Nancy I, France

Malajczuk N., Lapeyrie F. \& Garbaye J. (1989) Infectivity of two isolates of Pisolithus tincto- rius isolated from beneath pine and eucalypts respectively on roots of Eucalyptus urophylla in vitro. 1. Mycorrhizal formation in model systems. New Phytol. in press

Malajczuk N., Molina R. \& Trappe J.M. (1984) Ectomycorrhiza formation in eucalyptus. The ultrastructure of compatible and incompatible mycorrhizal fungi and associated roots. New Phytol. 96, 43-53

Massicotte H.B., Peterson R.L. \& Ashford A.E. (1987) Ontogeny of Eucalyptus pilularis-Pisolithus tinctorius ectomycorrhizae. I. Light microscopy and scanning electron microscopy. Can. J. Bot. 65, 1927-1939 